\title{
Screening for Raw Starch Digesting Bacteria
}

\author{
Pichet ITKor, Osamu SHIDA, * Norihiro Tsukagoshi \\ and Shigezo UDAKA ${ }^{\dagger}$ \\ Faculty of Agriculture, Nagoya University, Chikusa-ku, \\ Nagoya 464, Japan \\ * Research Laboratory, Higeta Shoyu Co., \\ Choshi, Chiba 288, Japan \\ Received June 30, 1988
}

\begin{abstract}
Screening for raw starch digesting bacteria revealed that bacteria producing amylase, which hydrolyzes raw starch, are widely distributed in nature. From among 155 raw starch digesting bacterial isolates, 20 strains were selected and examined as to both the characteristics of their enzymes and some bacteriological properties. According to the action patterns of their enzymes on starch, these strains could be divided into two groups, i.e., exolytic and endolytic amylase producers. The phenotypic properties of a representative bacterial isolate belonging to each group were examined. One of them (isolate TB1012) was assigned to Bacillus polymyxa (Prazmowski) Mace, which produced an exolytic $\beta$-amylase. The other (isolate B1018) was identified as Bacillus sp., which produced an endolytic amylase giving a single activity band corresponding to an approximate molecular weight of 75,000 on SDS-polyacrylamide gel electrophoresis.
\end{abstract}

In the course of conventional enzymatic saccharification, starch has to be gelatinized at first by cooking at a rather high temperature and liquefied with $\alpha$-amylase at the same time. In recent years, the importance of enzymatic saccharification of raw starch without heating has become well recognized, mainly from the viewpoints of energy saving and effective utilization of the biomass. Although effort has been made to achieve more efficient breakdown of raw starch, it is still worthwhile to search for a very active enzyme and to develop an efficient production system with such an enzyme.

It is more difficult for amylases to act on raw starch granules than on gelatinized starch. ${ }^{1)}$ Previous studies indicated that the saccharification of raw starch by amylolytic enzymes might be related to the extent of adsorption of an enzyme to the starch granules. Pancreatic $\alpha$ amylase and fungal glucoamylase adsorbed well to starch granules, which resulted in effective digestion of raw starch. ${ }^{2,3)}$ Although mi- croorganisms reported to be good producers of amylase capable of digesting raw starch have mostly been fungi, such as Aspergillus sp. ${ }^{3)}$ Rhizopus sp. ${ }^{4,5)}$ and Corticium rolfsii ${ }^{6}$, there have been reports of the possibility of raw starch degradation by bacterial $\alpha$ - and $\beta$ amylases. $^{7 \sim 9)}$

Our primary research aim here was to find novel bacterial amylases which efficiently hydrolyze raw starch, for practical use in the starch industry. By cloning the genes coding for such amylases and analyzing their structures, we may expect the very efficient production of raw starch digesting amylases through expression of the genes or genetically engineered genes in a host-vector system such as the Bacillus brevis system.

\section{Materials and Methods}

Microorganisms. All the bacteria were isolated from soil and compost from various places.

\footnotetext{
* To whom all correspondence should be addressed.
} 
Media. The media used in the screening were as follows. Medium A contained (g/l): raw corn starch, 5; polypepton, 0.5 ; and yeast extract, 0.1 . Medium $B$ contained $(\mathrm{g} / \mathrm{l})$ : raw corn starch, 5; $\left(\mathrm{NH}_{4}\right)_{2} \mathrm{SO}_{4}, 0.5 ;$ urea, $0.5 ; \mathrm{MgSO}_{4} \cdot 7 \mathrm{H}_{2} \mathrm{O}$, $0.05 ; \mathrm{K}_{2} \mathrm{HPO}_{4}, 0.5$; and yeast extract, 0.2. Raw starches were separately sterilized with ethylene oxide. Solid media contained $1.5 \%$ agar. $\mathrm{T}_{21}$ medium, used as the enzyme production medium, contained $(\mathrm{g} / \mathrm{l})$ : polypepton, 10 ; meat extract, 5; yeast extract, 2; and raw corn starch, 5.

Screening method. Each soil sample was suspended at the approximate ratio of $1 \mathrm{~g}$ of moist sample to $5 \mathrm{ml}$ of sterile water and then streaked onto the plates of the two screening media described above, of which the $\mathrm{pH}$ was adjusted to 4,7 or 10 . The plates were incubated at $30^{\circ} \mathrm{C}$ or $45^{\circ} \mathrm{C}$ for $72 \mathrm{hr}$. Bacteria that formed clear zones were purified by streaking on plates and single colonies were obtained. Each of the selected isolates was spotted onto screening agar plates containing 6 kinds of starch, which were kindly supplied by Dr. K. Kainuma of the National Institute of Food Science. They were corn, tapioca, potato, rice, wheat and soluble potato starches. After cultivation of the bacteria, the widths of the clear zones were determined. The isolates that formed rather large clear zones on starch agar plates were selected.

Enzyme Production. Each isolate was grown aerobically at $37^{\circ} \mathrm{C}$ or $45^{\circ} \mathrm{C}$ for $36 \mathrm{hr}$ in $30 \mathrm{ml}$ of $\mathrm{T}_{21}$ medium. After removal of cells by centrifugation $(5000 \mathrm{rpm}$ for $15 \mathrm{~min}$ at $4^{\circ} \mathrm{C}$ ), the supernatant was used to assay amylase activity.

Assaying of amylase activity. A reaction mixture, consisting of $1 \mathrm{ml}$ of a $0.5 \%(\mathrm{w} / \mathrm{v})$ raw corn starch suspension in $20 \mathrm{~mm}$ phosphate buffer, $\mathrm{pH} 7.0$, and $1 \mathrm{ml}$ of the enzyme solution, was incubated with gentle shaking at $37^{\circ} \mathrm{C}$ or $45^{\circ} \mathrm{C}$ for $4 \mathrm{hr}$. After removal of residual strach granules by centrifugation, the reducing sugar liberated was determined by the dinitrosalicylic acid method with glucose as the standard. ${ }^{10)}$ One unit of saccharifying activity was defined as the amount of enzyme which liberated $1 \mathrm{mg}$ of reducing sugar in $1 \mathrm{hr}$ under the assay conditions.

The soluble starch digesting activity was determined at $40^{\circ} \mathrm{C}$ by measurement of the dextrinizing power according to Fuwa. ${ }^{11)}$ The hydrolysis of $1 \mathrm{mg}$ of soluble starch in $1 \mathrm{hr}$ was defined as 1 unit of enzyme activity.

Action patterns on substrates. Multiple-ascent paper chromatography was performed for analysis of the products of enzymic hydrolysis as described by Kainuma and French. ${ }^{12)}$ The substrates used were soluble and raw corn starch, $\alpha$-cyclodextrin and $\beta$-cyclodextrin, at a concentration of $0.5 \%$. One part of the enzyme solution was added to four parts of a substrate solution, except for raw corn starch, where the enzyme solution to substrate solution ratio was $1: 1$. The reactions were carried out at $\mathrm{pH}$ 7.0 and $45^{\circ} \mathrm{C}$. Aliquots were withdrawn at various times and then boiled for 10 min to stop the reaction. When raw corn starch was used as the substrate, the reaction mixtures were centrifuged to remove residual starch granules before boiling. Twenty $\mu$ of each sample was spotted on Whatman No. 1 paper. After three to five ascents at room temperature with the solvent system of 1-propanol-water $(7: 3, v / v)$, the chromatograms were developed according to a silver nitrate dip procedure following glucoamylase treatment of the paper. ${ }^{12}$

Other methods. Extracellular protease activity was assayed qualitatively. Bacteria were grown on the nutrient agar medium containing $0.5 \%$ of skim milk at $37^{\circ} \mathrm{C}$ or $45^{\circ} \mathrm{C}$ for 2 days and then $5 \%$ TCA was poured onto the plates. Apparent protease activity was indicated by a clear zone around a colony. Sodium dodecyl sulfate(SDS)polyacrylamide gel electrophoresis was performed as described by Laemmli. ${ }^{13)}$ The amylase band in the gel after electrophoresis was detected in situ as described by Lacks and Springhorn. ${ }^{14)}$

Identification of the bacterial isolates. Cultural, morphological, physiological and biochemical characterization of the bacteria isolated was performed accordint to the methods recommended by Gordon et al. ${ }^{15)}$ and Komagata. ${ }^{16)}$ Bacillus polymyxa ATCC 842 (type strain) and $B$. circulans ATCC 4513 (type strain) were used as references. The results were analyzed using "Bergey's Manual of Determinative Bacteriology. ${ }^{17}$ ",

\section{Results}

\section{Screening for raw starch hydrolysing bacteria}

From one sample under one set of screening conditions, about 20 400 microorganisms grew on a plate, but only $1 \sim 5$ bacteria pro-

Table I. Distribution of Raw Corn Starch Digesting BACTERIA

\begin{tabular}{ccccc}
\hline $\begin{array}{c}\text { Screening } \\
\text { medium }\end{array}$ & $\begin{array}{c}\text { Temperature } \\
\left({ }^{\circ} \mathrm{C}\right)\end{array}$ & $\begin{array}{c}\text { Initial } \\
\mathrm{pH} \text { of the } \\
\text { medium }\end{array}$ & $\begin{array}{c}\text { Number of Percent } \\
\text { bacteria } \\
\text { isolated }\end{array}$ & $\begin{array}{c}\text { of total } \\
\text { isolates }\end{array}$ \\
\hline A & 30 & 4 & 31 & 20 \\
& 30 & 7 & 12 & 8 \\
& 30 & 10 & 9 & 6 \\
B & 30 & 4 & 19 & 12 \\
& 30 & 7 & 17 & 11 \\
& 30 & 10 & 14 & 9 \\
A & 45 & 4 & - & - \\
& 45 & 7 & 8 & 5 \\
& 45 & 10 & 11 & 7 \\
B & 45 & 4 & - & - \\
& 45 & 7 & 19 & 12 \\
& 45 & 10 & 15 & 10 \\
\hline
\end{tabular}


Table II. Characteristics of Some Raw Starch Digesting Bacteria

\begin{tabular}{|c|c|c|c|c|c|c|c|c|c|c|c|}
\hline \multirow{2}{*}{$\begin{array}{c}\text { Strain } \\
\text { number }\end{array}$} & \multirow{2}{*}{$\begin{array}{l}\text { Cultivation } \\
\text { temperature }\end{array}$} & \multirow{2}{*}{$\begin{array}{c}\text { Clear zone } \\
\text { on plate }\end{array}$} & \multirow{2}{*}{$\begin{array}{c}\text { Raw starch } \\
\text { saccharifying } \\
\text { activity }^{b}\left(\times 10^{2}\right)\end{array}$} & \multirow{2}{*}{$\begin{array}{c}\text { Soluble starch } \\
\text { liquefying } \\
\text { activity }^{b}\end{array}$} & \multirow{2}{*}{$\begin{array}{l}\text { Probable } \\
\text { amylase } \\
\text { type }^{c}\end{array}$} & \multicolumn{2}{|c|}{ Cell morphology } & \multirow{2}{*}{$\begin{array}{l}\text { Gram } \\
\text { stain }\end{array}$} & \multirow{2}{*}{$\begin{array}{c}\text { Spore } \\
\text { formation }\end{array}$} & \multirow{2}{*}{ Catalase } & \multirow{2}{*}{$\begin{array}{c}\text { Extracellular } \\
\text { protease }\end{array}$} \\
\hline & & & & & & Shape & Size $(\mu)$ & & & & \\
\hline A 406 & $37^{\circ} \mathrm{C}$ & ++ & 3.8 & 69 & exo & Rod & $0.9 \times 1 \sim 2.5$ & + & - & + & + \\
\hline A 407 & $37^{\circ} \mathrm{C}$ & + & - & 56 & & Rod & $0.6 \times 1 \sim 2$ & - & - & + & - \\
\hline A 1007 & $37^{\circ} \mathrm{C}$ & ++ & 4.8 & 64 & exo & Short rod & $0.3 \sim 0.5 \times 1$ & + & - & + & - \\
\hline A 1020 & $37^{\circ} \mathrm{C}$ & + & 1.0 & 612 & endo & Rod & $0.3 \times 1 \sim 1.2$ & + & + & + & - \\
\hline B 410 & $37^{\circ} \mathrm{C}$ & + & - & 510 & endo & Rod & $0.5 \sim 0.7 \times 1.5 \sim 2.5$ & - & - & - & + \\
\hline B 715 & $37^{\circ} \mathrm{C}$ & ++ & 17 & 794 & exo & Rod & $0.7 \sim 1 \times 2 \sim 3$ & - & - & - & + \\
\hline B 720 & $37^{\circ} \mathrm{C}$ & + & 1.8 & 456 & endo & Short rod & $0.3 \sim 0.5 \times 0.7 \sim 1.2$ & + & + & + & + \\
\hline B 1006 & $37^{\circ} \mathrm{C}$ & ++ & 2.5 & 54 & exo & Rod & $0.5 \times 1.5 \sim 4$ & - & - & - & - \\
\hline B 1007 & $37^{\circ} \mathrm{C}$ & + & 2.2 & 482 & endo & Short rod & $0.3 \sim 0.5 \times 1$ & + & + & + & - \\
\hline В 1012 & $37^{\circ} \mathrm{C}$ & + & - & 12 & & Rod & $0.5 \times 1.5$ & + & - & + & + \\
\hline TB 720 & $37^{\circ} \mathrm{C}$ & + & - & 372 & endo & Short rod & $0.5 \times 0.7 \sim 1.2$ & + & + & + & + \\
\hline TB $1012^{*}$ & $37^{\circ} \mathrm{C}$ & + & 13 & 792 & exo & Rod & $0.7 \sim 1 \times 2 \sim 5$ & + & + & + & + \\
\hline TB 1020 & $37^{\circ} \mathrm{C}$ & + & 1.0 & 548 & endo & Rod & $0.3 \times 1 \sim 1.2$ & $t$ & + & + & - \\
\hline A 723 & $45^{\circ} \mathrm{C}$ & $t+t$ & 5.5 & 34 & exo & Rod & $0.5 \times 3 \sim 5$ & + & - & + & + \\
\hline B 724 & $45^{\circ} \mathrm{C}$ & + & 15 & 728 & & Rod & $0.6 \times 1.5 \sim 3$ & + & + & + & - \\
\hline В 1009 & $45^{\circ} \mathrm{C}$ & + & 10 & 756 & & Rod & $0.4 \times 2 \sim 4$ & + & + & + & - \\
\hline B 1017 & $45^{\circ} \mathrm{C}$ & + & - & 778 & endo & Rod & $0.5 \sim 0.7 \times 1 \sim 4$ & + & + & + & + \\
\hline B 1018* & $45^{\circ} \mathrm{C}$ & ++ & 13 & 2640 & endo & Rod & $0.5 \sim 0.7 \times 2 \sim 5$ & - & + & + & + \\
\hline В 1019 & $45^{\circ} \mathrm{C}$ & ++ & 4.2 & 360 & exo & Rod & $0.6 \times 3 \sim 4$ & - & + & - & - \\
\hline B 1020 & $45^{\circ} \mathrm{C}$ & + & 2.0 & 728 & endo & Rod & $0.6 \times 1 \sim 3$ & + & + & + & - \\
\hline
\end{tabular}

* Reprèsentative raw starch digesting bacteria studied in more detail.

a Width of clear zones formed by the bacteria on raw corn starch containing plates.,$+ 1 \sim 2 \mathrm{~mm} ;++, 3 \sim 4 \mathrm{~mm} ;+++,>5 \mathrm{~mm}$.

$b$ The activity is expressed in units per $\mathrm{ml}$ of culture supernatant.

c The type was determined on the basis of the starch digesting activities. An amylase showing higher saccharifying activity relative to the liquefying activity was regarded as being of the exo-type and one showing the opposite was assumed to be of the endo-type. 
duced clear zones around their colonies on raw starch plates. Although the isolates were screened under different growth conditions, i.e., with varying medium components, $\mathrm{pH}$ and temperature, probable duplicates, i.e., bacteria isolated from the same sample and possessing the same colony morphology, were omitted. A total of 155 isolates were obtained from 25 soil and compost samples. Table I shows the numbers of raw starch hydrolysing bacteria isolated under the different conditions.

All the 155 isolates were then spotted onto screening agar plates containing six kinds of starches. Twenty isolates were selected which exhibited the ability to hydrolyse almost every kind of starch. After cultivation of these 20 isolates in liquid medium $\mathrm{T}_{21}$, both soluble starch digesting and raw corn starch saccharifying activities were determined as described under Materials and Methods (Table II). Some of the isolates formed clear zones on the agar plates but did not show any raw starch saccharifying activity. This might be because the cultivation conditions were not yet optimal. The bacteria produced enzymes which showed soluble starch liquefying activity and raw starch saccharifying activity of various levels. Some of the microbiological properties are also shown in Table II. Many good amylase producers were gram-positive rods and catalase positive. Some of them produced proteases. Two isolates, A1007 and TB1012, which produced amylases in higher amounts than other isolates grown at $30^{\circ} \mathrm{C}$, and three strains, B724, B1009 and B1018, which were apparently good amylase producers among those isolated at $45^{\circ} \mathrm{C}$, were selected for further studies.

\section{Properties of amylases produced by the selected bacteria}

The action patterns of amylases produced by strains B724, B1009 and B1018, which were isolated at $45^{\circ} \mathrm{C}$, on soluble or raw corn starch were similar. The pattern of $\mathrm{B} 1018$ is shown in Fig. 1A. At early stages of the reaction, higher molecular-weight oligosaccharides were the major products. As the reaction proceeded, the quantities of $\mathrm{G}_{1}-\mathrm{G}_{4}$ increased. The enzyme could liberate a series of low molecular-weight saccharides when $\alpha$ - or $\beta$-cyclodextrin was
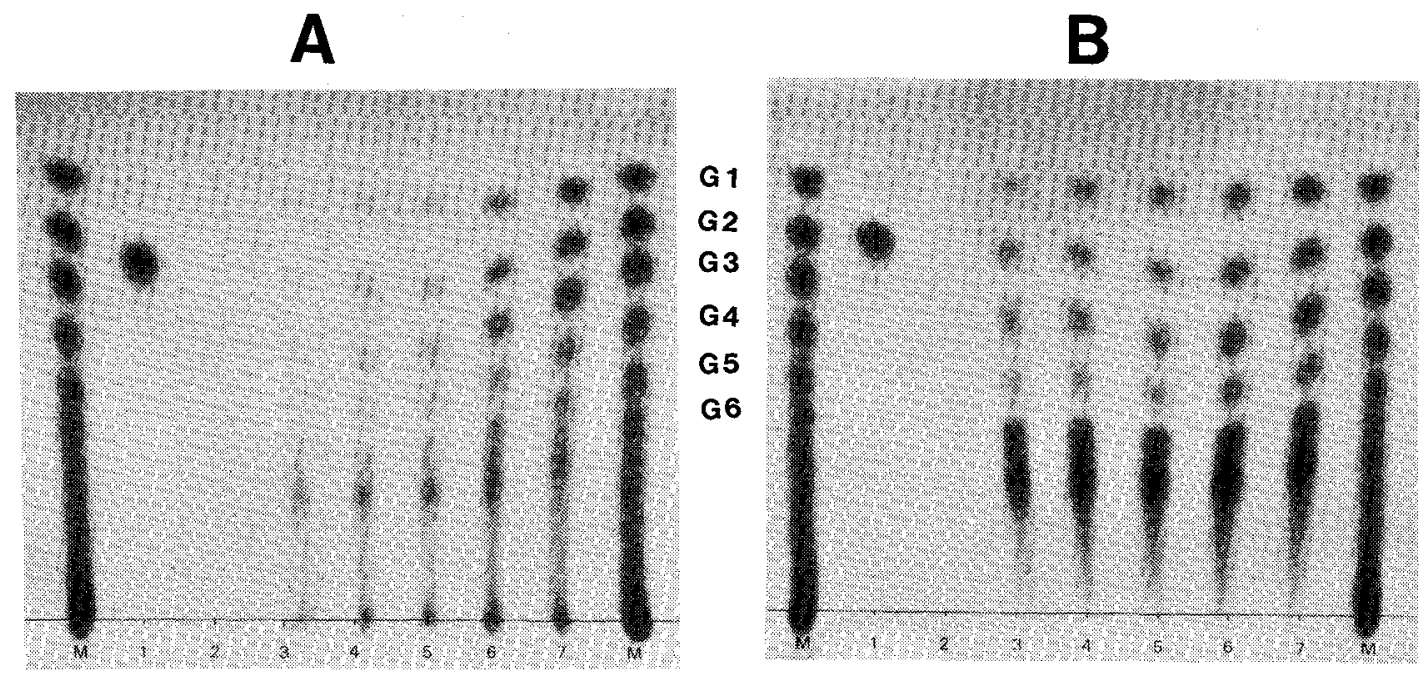

Fig. 1. Paper Chromatograms of the Products formed from Raw Corn Starch (A) and $\alpha$-Cyclodextrin (B) by the B1018 Amylase.

Chromatography was performed as described under Materials and Methods. The culture supernatant of B1018 was concentrated 8 times by $20 \sim 80 \%$ ammonium sulfate precipitation and then used to digest raw corn starch. 2 to 7 , aliquots of the reaction mixture withdrawn at $0,10,20,30,60$ and $120 \mathrm{~min}$ incubation, respectively; $\mathbf{M}$, standard oligosaccharides; 1 , maltose. 
used as the substrate. The product derived from $\alpha$-cyclodextrin is shown in Fig. 1B. These observations suggest that the enzymes are of the endolytic type. In the case of strains A 1007 and $\mathrm{TB} 1012$, which were isolated at $30^{\circ} \mathrm{C}$, the action patterns on starch were different from those of the amylases of the bacteria (B724, B1009 and B1018) isolated at $45^{\circ} \mathrm{C}$. The amylase of strain A1007 could be considered, from its action pattern, to be of the endolytic

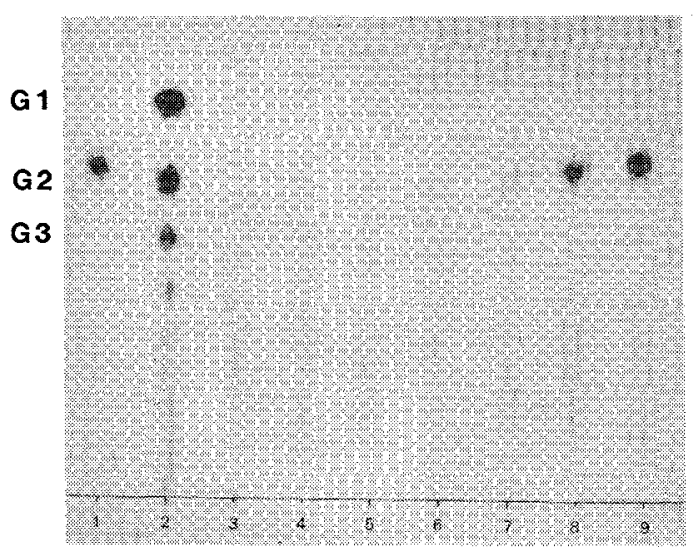

Fig. 2. Paper Chromatogram of the Products formed Raw Corn Starch by the TB1012 Amylase.

Chromatography was performed as described under Materials and Methods. The reaction mixture contained the culture supernatant of TB1012 and the raw corn starch suspension in the ratio of $1: 1.1$, maltose; 2 , standard oligosaccharides; 3 to 9 , aliquots of the reaction mixture withdrawn at $0,10,20,30,60,120$ and $240 \mathrm{~min}$, respectively.

A

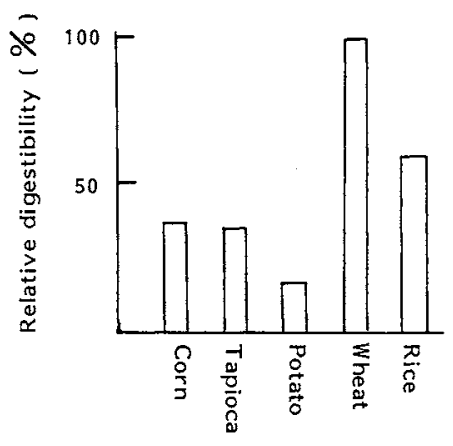

type, but it digested neither $\alpha$ - nor $\beta$-cyclodextrin, even on prolonged incubation (data not shown). When the amylase of strain TB1012 was used, the main product at various stages of hydrolysis of soluble starch or raw corn starch was apparently maltose (Fig. 2). This enzyme liberated some low molecular weight oligosaccharides, mainly maltose, when $\beta$-cyclodextrin was used as the substrate, but did not liberate any when the substrate was $\alpha$-cyclodextrin. Such different action patterns cause much difficulty when determining whether an enzyme is of the endolytic or exolytic type, and might suggest that A 1007 and TB1012 produce more than one type of amylase.

Figure 3 shows that the activities toward various raw starches of two representative isolates, TB1012 and B1018, varied considerably, and they were weak in digesting raw potato starch, which is known to be often resistant to amylases of microbial, plant and animal origin.

The number of amylase activity bands as well as the extracellular protein composition were determined by SDS-polyacrylamide gel electrophoresis. The crude enzymes from strains B1018 and B724 each gave one activity band corresponding to an approximate molecular weight 75,000 . The crude enzyme of strain TB1012 gave at least four activity bands with molecular weights ranging from 40,000 to 100,000 (Fig. 4B). Apparently, these bacteria

B

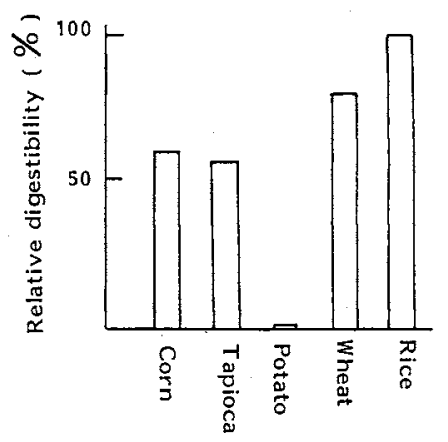

Fig. 3. Comparison of the Digestibilities of Various Raw Starches.

The saccharifying activities of the amylases produced by TB1012 (A) and B1018 (B) toward each raw starch were analyzed as described under Materials and Methods. The relative activities are shown on the ordinate. 


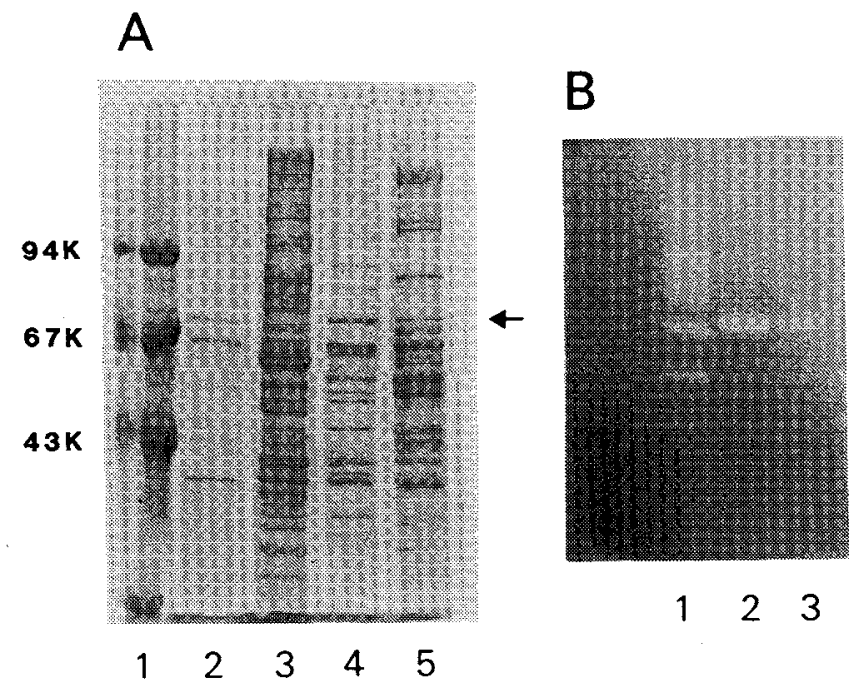

Fig. 4. SDS-Polyacrylamide Gel Electrophoresis of the Culture Supernatants of Raw Starch Digesting Bacteria.

Electrophoresis was performed as described under Materials and Methods. Panel A: Protein staining with Coomassie blue. Lane 1, marker proteins; lane 2, A1007; lane 3, TB1012; lane 4, B1018; and lane 5, B724. Panel B: in situ detection of amylase activity. Lane 1, TB1012; lane 2, B1018; and lane 3, B724. The arrow indicates the protein bands of B1018 and B724 which migrated the same distance as the amylase activity band.

produced various kinds of extracellular proteins (Fig. 4A).

Figure 5 shows the effect of temperature on the soluble starch digesting activity of the enzymes. A similar effect was seen on the raw starch saccharifying activity. The enzyme of strain B1018 showed relatively high thermal stability, nearly $100 \%$ amylase activity being retained even after incubation for $30 \mathrm{~min}$ at $55^{\circ} \mathrm{C}$. Strain TB1012 produced amylases with a lower thermal stability, the enzyme being stable up to about $45^{\circ} \mathrm{C}$.

\section{Characterization of the two raw starch digesting bacteria}

The characteristics of strains TB1012 and B1018 are shown in Table III. Chemotaxonomical studies and analysis of the DNA base composition, which were not performed in the present work, are necessary for definitive identification of these bacteria. Their phenotypic properties, see Table III, however, indicate that they both belong to the genus Bacillus. Isolate TB1012 is assigned to Bacillus polymyxa (Prazmowski) Mace, although

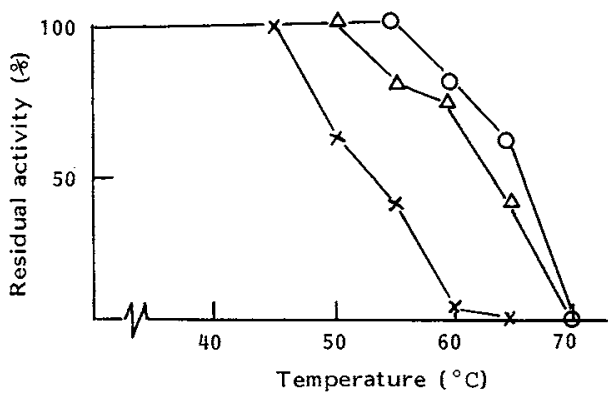

Fig. 5. Effect of Temperature on the Enzyme Stability.

The culture supernatant was made to $10 \mathrm{mM} \mathrm{CaCl}_{2}, 50 \mathrm{~mm}$ Tris- $\mathrm{HCl}$, pH 7.5, by adding the respective concentrated solutions, followed by incubation at different temperatures for $30 \mathrm{~min}$. The residual activity was assayed after cooling to room temperature. $\mathrm{O}, \mathrm{B} 1018 ; \triangle, \mathrm{B} 724 ; \times, \mathrm{TB} 1012$.

it has some characteristics that are different from those of B. polymyxa; i.e., it did not reduce nitrate and did not form gas from $\mathrm{D}$-xylose. On the other hand, isolate B1018 was similar to B. circulans in some respects, but could not be identified as a definite species. Although $B$. circulans could not grow above $50^{\circ} \mathrm{C}, \mathrm{B} 1018$ grew even at $55^{\circ} \mathrm{C} . \mathrm{B} 1018$ did not produce acid from fructose, trehalose or 
Table III. Phenotypic Characterization of Strains TB1012 and B 1018

\begin{tabular}{|c|c|c|}
\hline & TB1012 & B1018 \\
\hline \multicolumn{3}{|l|}{ Cultural characteristics } \\
\hline \multicolumn{3}{|l|}{ Nutrient agar colonies: } \\
\hline & $\begin{array}{l}\text { Moderate growth, smooth, round, } \\
\text { yellowish-grey, flat }\end{array}$ & $\begin{array}{l}\text { Good growth, smooth, rhizoid, } \\
\text { pale yellow-brown, flat }\end{array}$ \\
\hline \multicolumn{3}{|l|}{ Nutrient agar slant: } \\
\hline & $\begin{array}{l}\text { Moderate growth, smooth or slightly } \\
\text { rough, yellowish-grey }\end{array}$ & $\begin{array}{l}\text { Moderate growth, smooth or slightly. } \\
\text { rough, yellowish-grey }\end{array}$ \\
\hline Nutrient broth: & $\begin{array}{l}\text { Slight turbidity, formation of a } \\
\text { pellicle and a tiny amount of precipitate }\end{array}$ & $\begin{array}{l}\text { Slight turbidity, no pellicle formation, } \\
\text { a small amount of precipitate }\end{array}$ \\
\hline \multirow[t]{2}{*}{ Gelatin stub: } & Growth on the surface, some & Growth on the surface, some \\
\hline & liquefaction & liquefaction \\
\hline Litmus milk: & No reduction, liquefaction & No change \\
\hline \multicolumn{3}{|c|}{ Morphological characteristics } \\
\hline \multirow{2}{*}{\multicolumn{2}{|c|}{$\begin{array}{l}\text { Rods, } 0.7 \sim 0.9 \times 3 \sim 4 \mu \mathrm{m} \\
\text { Non-pleomorphic }\end{array}$}} & Rods, $0.5 \sim 0.7 \times 2 \sim 5 \mu \mathrm{m}$ \\
\hline & & \\
\hline \multicolumn{2}{|r|}{ motile, peritrichous flagella } & motile, peritrichous flagella \\
\hline \multicolumn{2}{|r|}{ endospore forming, heat resistant } & \\
\hline \multicolumn{2}{|r|}{ Spores: spherical, $1 \sim 1.2 \mu \mathrm{m}$} & \multirow{2}{*}{$\begin{array}{l}\text { Spores: spherical, } 0.8 \sim 1 \mu \mathrm{m} \text {, central } \\
\text { or terminal location, swollen sporangium } \\
\text { gram negative and non-acid fast }\end{array}$} \\
\hline \multicolumn{2}{|r|}{$\begin{array}{l}\text { central location, swollen sporangium } \\
\text { gram positive and non-acid fast }\end{array}$} & \\
\hline \multicolumn{3}{|c|}{ Physiological and biochemical characteristics } \\
\hline Nitrate reduced to nitrite: & Negative & Negative \\
\hline Denitrification: & Negative & Negative \\
\hline V-P test: & Positive & Negative \\
\hline $\mathrm{pH}$ in $\mathrm{V}-\mathrm{P}$ broth & $<6$ & $<6$ \\
\hline MR test: & Negative & Positive \\
\hline Catalase: & Positive & Positive \\
\hline Oxidase; & Negative & Negative \\
\hline Urease: & Negative & Negative \\
\hline \multicolumn{3}{|l|}{ Formation of } \\
\hline Indole & Negative & Negative \\
\hline Hydrogen sulfide & Positive & Positive \\
\hline \multicolumn{3}{|l|}{ Utilization of } \\
\hline Citrate & Negative & Negative \\
\hline Nitrate or ammonia & Positive & Positive \\
\hline O-F test: & Fermentation & No decomposition \\
\hline Oxygen relation: & Facultative anaerobic & Aerobic \\
\hline \multirow[t]{2}{*}{ Growth range: } & $\mathrm{pH} 6 \sim 8$ & $\mathrm{pH} 6 \sim 8.5$ \\
\hline & up to $43^{\circ} \mathrm{C}$ & up to $55^{\circ} \mathrm{C}$ \\
\hline \multicolumn{3}{|l|}{$\mathrm{pH}$ and temperature for } \\
\hline good growth: & $\mathrm{pH} 6,30 \sim 40^{\circ} \mathrm{C}$ & $\mathrm{pH} 6,35 \sim 45^{\circ} \mathrm{C}$ \\
\hline Growth in $\mathrm{NaCl}$ & No growth in about $2 \%$ & $\begin{array}{l}\text { Grow in } 2 \%, \text { no growth } \\
\text { in about } 5 \% \mathrm{NaCl}\end{array}$ \\
\hline Water soluble pigment: & Negative & Negative \\
\hline Hydrolysis of casein: & Positive & Positive \\
\hline Hydrolysis of starch: & Positive & Positive \\
\hline Hydrolysis of DNA: & Negative & Negative \\
\hline \multicolumn{3}{|c|}{ Acid or gas production from sugars: } \\
\hline & Both acid and gas from D-glucose, & Acid but no gas from D-glucose, \\
\hline & L-arabinose, D-mannose, D-galactose, & L-arabinose, D-mannose, D-galactose, \\
\hline & maltose, sucrose, lactose, trehalose, & maltose, sucrose, lactose, starch, \\
\hline & D-mannitol, glycerol, starch, & D-xylose. No acid and no gas from \\
\hline & D-fructose. Acid but no gas from & D-fructose, trehalose, D-sorbitol, \\
\hline & D-xylose, D-sorbitol. No acid and & D-mannitol, inositol, glycerol, \\
\hline & no gas from inositol. & \\
\hline
\end{tabular}


mannitol, whereas B. circulants ATCC 4513 did. Tentatively, we named it Bacillus sp. strain B1018.

\section{Discussion}

On screening, it became clear that raw starch digesting bacteria are widely distributed in nature and are able to grow under various growth conditions, such as different temperatures and pHs (Table I). However, when a medium with an acidic initial $\mathrm{pH}$ was used, such bacteria were isolated from among those grown at $30^{\circ} \mathrm{C}$, but not those grown at $45^{\circ} \mathrm{C}$. During the course of screening, it was observed that many fungi and streptomyces-like organisms formed large clear zones on raw starch plates. Since the next aim of our research was to analyze the gene for a raw starch digesting enzyme, we only selected bacteria which produce a raw starch digesting amylase, the gene for which may be easy to analyze.

The starch liquefying and saccharifying activities of the amylases produced by the selected bacteria suggested that there are mainly two groups of bacteria, one of which produces an exolytic amylase and the other an endolytic amylase (Table II). Strain TB1012 was identified as $B$. polymyxa and produced an enzyme which exclusively formed maltose from starch (Fig. 2). Bacillus polymyxa is known to produce $\beta$-amylase, which splits starch into maltose in a stepwise fashion from its nonreducing end, and to produce multiple $\beta$ amylases with different molecular weights. ${ }^{18)}$ Therefore, TB1012 is most likely a $\beta$-amylase producing bacterium.

On the other hand, strain B1018 produced an amylase which appeared to split starch endolytically (Fig. 1) and gave one activity band upon SDS-polyacrylamide gel electrophoresis, as shown in Fig. 3B. Although there have been a few reports on raw starch digesting amylases produced by bacteria, ${ }^{7,9,19)}$ they seem to differ from that produced by Bacillus sp. B1018 in some respects, such as the action patterns on starches and molecular weight. Although the B1018 amylase can digest raw potato starch only poorly, the latter is well degraded by the amylase of $B$. circulans. ${ }^{8)}$ The microbiological properties of B1018 are also different from those of raw starch digesting $B$. circulans $^{8)}$ and B. subtilis ${ }^{19)}$ (Table III). A detailed study on the B1018 enzyme will be described in a subsequent report.

Acknowledgment. This research was supported in part by a Grant-in-Aid for Scientific Research on Priority Areas from the Ministry of Education, Science and Culture of Japan

\section{References}

1) G. J. Walker and P. M. Hope, Biochem. J., 86, 452 (1963).

2) I. Yamasaki and S. Ueda, J. Agric. Chem. Soc. Jpn, 24, 181 (195I).

3) S. Ueda, Bull, Agric. Chem. Soc. Jpn., 21, 284 (1957).

4) B. C. Saha and S. Ueda, J. Ferment. Technol, 61, 67 (1983).

5) S. Ueda and S. Kano, Die Stärke, 27, 123 (1975).

6) S. Takao, H. Sasaki, K. Kurosawa, M. Tanida and Y. Komagata, Agric. Biol. Chem., 50, 1979 (1986).

7) K. Mizokami, M. Ozaki and K. Kitahara, J. Jpn. Soc. Starch Sci., 25, 132 (1978).

8) H. Taniguchi, F. Odashima, M. Igarashi, Y. Maruyama and M. Nakamura, Agric. Biol. Chem., 46, 2107 (1982).

9) M. Hoshino, Y. Hirose, K. Sano and K. Mitsugi, Agric. Biol. Chem., 39, 2415 (1975).

10) P. Bernfeld, "Methods in Enzymology," Vol. 1, ed. by S. P. Colowick and N. O. Kaplan, Academic Press Inc., New York, 1955, p. 149

11) H. Fuwa, J. Biochem. (Tokyo), 41, 583 (1954).

12) K. Kainuma and D. French, FEBS Lett., 5, 257 (1969).

13) U. K. Laemmli, Nature (London), 227, 680 (1970).

14) S. A. Lacks and S. S. Springhorn, J. Biol. Chem., 255, $7467(1980)$.

15) R. E. Gordon, W. C. Haynes and C. H.-N. Pang, "The Genus Bacillus," Agricultural Research Service, U.S. Department of Agriculture, Washington D.C., 1973.

16) K. Komagata, "Biseibutsu no Bunrui to Doutei," ed. by T. Hasegawa, Gakkai Shuppan Center, Tokyo, 1985, p. 203.

17) "Bergey's Manual of Systematic Bacteriology," Vol. 2, Williams and Wilkins, Battimore, 1986, p. 1104.

18) T. Kawazu, Y. Nakanishi, N. Uozumi, T. Sasaki, H. Yamagata, N. Tsukagoshi and S. Udaka, $J$. Bacteriol., 169, 1564 (1987).

19) S. Hayashida, Y. Teramoto and T. Inoue, Appl. Env. Microbiol., 54, 1516 (1988). 